\title{
強震を受ける損傷制御型二層ブレース構造物の層間変形集中に対する ブレース材の二次剛性の影響 \\ EFFECT OF POST YIELDING STIFFNESS OF BUCKLING RESTRAINT BRACES ON MECHANISM OF DAMAGE CONTROL FOR TWO STORY BRACED FRAME WITH RESTRAINT BRACES
}

\author{
木村祥 裕*, 御幡 結**, 中澤 泰 典 $^{* * *}$ \\ Yoshihiro KIMURA, Yui MIHATA and Yasunori NAKAZAWA
}

\begin{abstract}
In general, the column moment demands in steel concentrically braced frames are ignored. However, large concentrations of damage are not seen in real frames since columns are continuous and they possess some flexural stiffness and strength. This paper clarifies the effect of continuous columns and the post yielding stiffness of buckling restraint braces on mechanism of damage control for two story braced frame with restraint braces on pushover and dynamic analyses. It is shown that continuous seismic and gravity columns and the post yielding stiffness of braces in a structure significantly decrease the possibility of large drift concentrations.
\end{abstract}

Keywords: Two Story Braced Frame, Damage Control System, Drift Concentration Factor, Ratio of Column Flexural Stiffness, Post Yielding Stiffness of Braces

二層ブレース架構，損傷分散型システム，層間変形集中率，柱材曲け剛性比，ブレース材二次剛性

\section{1. 序}

二層構造物の層間変形集中に及ぼす各種構造特性の影響を明らか

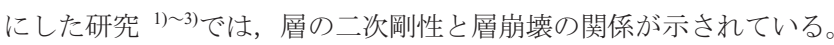
バイリニア型と仮定した層では, 降伏後の層剛性の変化は急激となる ため, 特定層への層間変形集中を回避するには降伏後も高い層剛性を 必要とする。

一方, 著者らが提示した主抵抗要素と二次抵抗要素で構成される二 層構造物では, 仮に主抵抗要素の二次剛性が 0 であっても二次抵抗要 素による応力再配分機構により層間変形集中の抑制が可能となるこ

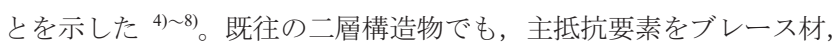
二次抵抗要素を柱材としている構造物が見られるものの, 柱材による 応力再配分機構を積極的に取り入れてメカニズムを検討したものと は言い難い。文献 9)，10)ではこのような二次抵抗要素による層間変 形集中の緩和効果の重要性を指摘しており, 二相系構造物の地震応答 性状に関する研究 ${ }^{1112)}$ も著者ら以外にも見受けられるが, 定性的な把 握であり, 二次抵抗要素の要求性能は明らかにされていない。

このような複数の耐震機構を有する構造物は「二相系構造物(Dual System)」と呼ばれ, 米国の Design Code である IBC2003 ${ }^{13)}$, AISC2006 ${ }^{14)}$ では Response Modification Coefficient $R$ factor がラーメン構造物と同等 の性能として $R=8$ と定められている。

また, 二相系構造物として, 座屈拘束型ブレースによる制振架構が 挙げられるが, 座屈拘束型ブレースはブレース材の歪硬化勾配等によ り降伏後に二次剛性を有し, 層間変形集中を緩和寸る効果を発揮する。
一方, ブレース材が降伏し, 二次抵抗要素である柱材が応力再配分機 構を形成した後も, ブレース材の二次剛性によって層せん断力は増加 するため, 柱材の作用せん断力も増加する。その結果, 完全弾塑性で あるブレース材の場合には想定しない崩壊機構を形成する可能性が ある。

本論文では, 主抵抗要素であるブレース材降伏後の二次剛性が二相 系構造物の層間変形集中に及ぼす影響と二次抵抗要素である柱材に よる層間変形集中抑制効果について明らかにする。水平外力を受ける 構造物の静的釣合いを仮定し, 層間変形集中率の評価式を導く。ブレ 一ス材の二次剛性, 柱材曲げ剛性やブレース架構の塑性率から層間変 形集中率や柱材への作用モーメントを明らかにする。さらに，構造物 に損傷を及ぼすレベルの強震が作用した場合に, 慣性力等の動的効果 が上記の構造特性と要求性能との関係に及ぼす影響を検討する。

\section{2. ブレース材が二次剛性を有する損傷制御型二層ブレース構造物の 層間変形と柱材作用モーメント}

二層ブレース構造物を構成する部材の剛性, 耐力と構造物の層間変 形との関係を釣合方程式により明らかにする。

\section{1 二層ブレース構造物の層間変形及び柱材作用モーメントに 対する静的釣合いの仮定条件 \\ ブレース材が二次剛性を有する二層ブレース構造物の崩壊機構を 把握するために, 水平外力に対するブレース架構の静的釣合いにより}

\footnotetext{
* 長崎大学工学部構造工学科 教授・博士 (工学)

** 大分市役所 修士 (工学)

(元 長崎大学大学院生)

*** 翔栄建築設計事務所
}

Prof., Dept. of Structural Engineering, Nagasaki University, Dr. Eng. Oita City Officer, M. Eng.

Shouei Architect \& Engineers LTD. 
評価式を誘導する。その際，以下の仮定を用いる。 1) 二層ブレース構造物では, 施工性の観点から梁 材をウェブボルト接合のみで柱材に取り付ける場合 が多いことから，梁材及びブレース材両端はピン接 合とし, 柱材及び梁材に作用する軸変形は無視する。 これは，二層ブレース架構の層間変形集中に対して 軸変形の影響は小さいことが文献 6）で明らかにさ れているためである。

2 ）通し柱材を弾性とし，通し柱材の柱脚をピン支 持とする。二層構造物の場合, 柱脚に作用する軸力 は小さく，また弾性範囲であれば軸力による剛性低

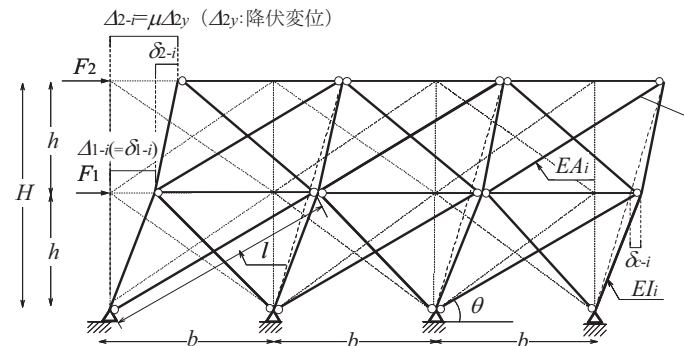

(a) 二層ブレース架構モデル

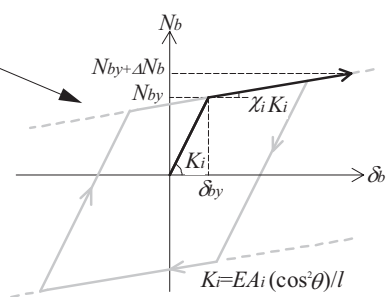

(b) 材料特性

図 1 二層ブレース架構のモデル化

ハイフンの後ろの数字は塑性率，降伏順序の各段階を表している。 1)下層のブレース材が降伏するまでの上下層変位 $(\mu \leqq 1)$

架構全体，ブレース架構部分，全ての柱材のそれぞれの系に作用寸 るせん断力 $V_{s i-1}, \quad V_{f i-1}, V_{c-1}(i=1,2)$ の関係, 及び全ての柱材に作用す るせん断力 $V_{c-1}$ と柱の曲げ変形に伴う通し柱材中央(高さ $h$ ) での水平 変位 $\delta_{c-1}$ の関係は, 文献 4) と同様, 上述の仮定及び図 1 (a)より次式と なる。

$$
\begin{aligned}
& V_{s 1-1}=V_{f 1-1}+V_{c-1}, V_{s 2-1}=\varphi V_{s 1-1}, V_{s 2-1}=V_{f 2-1}-V_{c-1} \\
& V_{c-1}=\frac{l^{3}}{E A b^{2}} 3 \alpha \delta_{c-1}
\end{aligned}
$$

ここで，EA は(1)式に示すブレース材の軸剛性の和である。 $\mu \leqq 1$ では, 上下層の水平変位 $\delta_{1-1}, \Delta_{2-1}$ はブレース架構の上下層に作 用するせん断力 $V_{f 1-1}, V_{f 2-1}$ により次式で表される。

$$
\delta_{1-1}=\frac{l^{3}}{E A b^{2}} V_{f 1-1}, \Delta_{2-1}=\delta_{1-1}+\delta_{2-1}=\frac{l^{3}}{E A b^{2}}\left(V_{f 1-1}+\frac{V_{f 2-1}}{\beta}\right)
$$

ここで， $\beta$ は高さ方向のせん断剛性・耐力比， $\delta_{2-1}$ は上層の層間変形 である。また， $l, b, h, H$ は図 1 に示寸とおりである。下層の降伏 せん断耐力を $V_{f l y}$ とすると，(2) (4)式から上下層の水平変位 $\delta_{1-1}, \Delta_{2-1}$ は次式で表される。

$$
\delta_{1-1}=\frac{l^{3}}{E A b^{2}} V_{f 1 y}, \Delta_{2-1}=\delta_{1-1}+\frac{l^{3}}{E A b^{2}} \frac{2 \varphi+3 \alpha(\varphi+1)}{2 \beta+3 \alpha(\varphi+1)} V_{f 1 y}
$$

ここで, $\varphi\left(=\mathrm{A}_{2} W_{2} / \mathrm{A}_{1} W_{1}, \mathrm{~A}_{\mathrm{i}}: \mathrm{A}_{\mathrm{i}}\right.$ 分布による係数, $W_{i}$ : 各層の重量 $)$ は上下層のせん断力比である。全ての柱材及び上層のブレース架構に 作用寸るせん断力 $V_{c-1}, \quad V_{f 2-1}$ は下層の降伏せん断耐力 $V_{f y}$ により次式 で表される。

$$
\begin{aligned}
& V_{c-1}=\frac{3 \alpha(\beta-\varphi)}{2 \beta+3 \alpha(\varphi+1)} V_{f 1 y} \\
& V_{f 2-1}=\frac{2 \varphi+3 \alpha(\varphi+1)}{2+3 \alpha(\varphi+1) / \beta} V_{f 1 y}
\end{aligned}
$$

2) $\mu 1$ から上下層ブレース材が降伏するまでの上下層変位増分

1)以降, 寸なわち下層ブレース材降伏後 $(\mu>1)$ から上下層のブレー ス材降伏までのせん断力増分及び全ての柱材のせん断力の増分は(2), (3)式と同様，次式で表される。

$$
\begin{aligned}
& \Delta V_{s 1-2}=\Delta V_{f 1-2}+\Delta V_{c-2}, \Delta V_{s 2-2}=\varphi \Delta V_{s 1-2}, \Delta V_{s 2-2}=\Delta V_{f 2-2}+\Delta V_{c-2} \text { (8) } \\
& \Delta V_{c-2}=\frac{l^{3}}{E A b^{2}} 3 \alpha \delta_{c-2}
\end{aligned}
$$

$\mu \gg 1$ から上下層ブレース材が降伏するまでについては，上下層の水 平変位の増分 $\delta_{1-2}, \Delta_{2-2}$ は，ブレース架構の上下層に作用するせん断力 の増分 $\Delta V_{f 1-2}, \Delta V_{\rho 2-2}$ により次式で表される。 
$\delta_{1-2}=\frac{l^{3}}{\chi_{1} E A b^{2}} \Delta V_{f 1-2}, \Delta_{2-2}=\delta_{1-2}+\delta_{2-2}=\frac{l^{3}}{E A b^{2}}\left(\frac{\Delta V_{f 1-2}}{\chi_{1}}+\frac{\Delta V_{f 2-2}}{\beta}\right)$

ここで， $\chi_{i}(i=1,2)$ はブレース材二次剛性比である。下層の降伏せ ん断耐力 $V_{f y}$ により, (8) (10)式から上下層に作用するせん断力の増分 $\Delta V_{f 1-2}, \Delta V_{\rho 2-2}$ は, 次式で表される。

$$
\begin{aligned}
& \Delta V_{f 1-2}=\frac{\chi_{1}(\mu-1)\{2 \beta+3 \alpha(\varphi+1)\}}{2\left\{\beta+\varphi \chi_{1}+3 \alpha(\varphi+1)\right\}}\left\{\frac{2 \varphi+3 \alpha(\varphi+1)}{2 \beta+3 \alpha(\varphi+1)}+1\right\} V_{f 1 y} \\
& \Delta V_{f 2-2}=\frac{(\mu-1) \beta\left\{2 \varphi \chi_{1}+3 \alpha(\varphi+1)\right\}}{2\left\{\beta+\varphi \chi_{1}+3 \alpha(\varphi+1)\right\}}\left\{\frac{2 \varphi+3 \alpha(\varphi+1)}{2 \beta+3 \alpha(\varphi+1)}+1\right\} V_{f 1 y}
\end{aligned}
$$

また, 上下層の水平変位の増分 $\delta_{1-2}, \Delta_{2-2}$ は(10) (12)式より次式で表 される。

$$
\begin{aligned}
& \delta_{1-2}=\frac{(\mu-1)\{2 \beta+3 \alpha(\varphi+1)\}}{2\left\{\beta+\varphi \chi_{1}+3 \alpha(\varphi+1)\right\}}\left\{\frac{2 \varphi+3 \alpha(\varphi+1)}{2 \beta+3 \alpha(\varphi+1)}+1\right\} \frac{l^{3}}{E A b^{2}} V_{f 1 y} \\
& \Delta_{2-2}=(\mu-1) \Delta_{2 y}=(\mu-1)\left\{\frac{2 \varphi+3 \alpha(\varphi+1)}{2 \beta+3 \alpha(\varphi+1)}+1\right\} \frac{l^{3}}{E A b^{2}} V_{f 1 y}
\end{aligned}
$$

また, 全ての柱材に作用するせん断力増分 $\Delta V_{c-2}$ は下層の降伏せん断 耐力 $V_{f y}$ により次式で表される。

$$
\Delta V_{c-2}=\frac{3 \alpha(\mu-1)\left(\beta-\varphi \chi_{1}\right)}{2\left\{\beta+\varphi \chi_{1}+3 \alpha(\varphi+1)\right\}}\left\{\frac{2 \varphi+3 \alpha(\varphi+1)}{2 \beta+3 \alpha(\varphi+1)}+1\right\} V_{f 1 y}
$$

3)上下層ブレース材がともに降伏した後の上下層変位増分

2)以降，すなわち上下層ブレース材が降伏した後のせん断力及び全 ての柱材のせん断力の増分は(2), (3)式と同様, 次式で表される。

$$
\begin{aligned}
& \Delta V_{s 1-3}=\Delta V_{f 1-3}+\Delta V_{c-3}, \Delta V_{s 2-3}=\varphi \Delta V_{s 1-3}, \Delta V_{s 2-3}=\Delta V_{f 2-3}-\Delta V_{c-3} \\
& \Delta V_{c-3}=\frac{l^{3}}{E A b^{2}} 3 \alpha \delta_{c-3}
\end{aligned}
$$

上下層ブレース材がともに降伏した後の変位増分 $\delta_{1-3}, \Delta_{2-3}$ を求める ために，上下層ブレース材がともに降伏するときの塑性率 $\mu_{\mathrm{s}}$ を算定す る。上下層ブレース材が降伏するとき, 上層の降伏せん断耐力 $V_{\rho 2 y}$ 及 びせん断力 $V_{\rho 2-1}, \Delta V_{\rho-2}$ の関係は次式となる。

$$
V_{f 2 y}-V_{f 2-1}=\Delta V_{f 2-2}
$$

また，(7)，(12)，(20)式より上下層ブレース材が降伏するときの塑 性率 $\mu_{s}$ は次式で表される。

$$
\mu_{s}=1+\frac{2\left\{\beta+\varphi \chi_{1}+3 \alpha(\varphi+1)\right\}(\beta-\varphi)}{\left\{2 \varphi \chi_{1}+3 \alpha(\varphi+1)\right\}\{\varphi+\beta+3 \alpha(\varphi+1)\}}
$$

$\mu_{\mathrm{s}}<\mu$ では，上下層の水平変位の増分 $\delta_{1-3}, \Delta_{2-3}$ は，ブレース架構の 上下層に作用するせん断力の増分 $\Delta V_{f-3-3}, \Delta V_{f 2-3}$ により次式で表される。

$$
\delta_{1-3}=\frac{l^{3}}{\chi_{1} E A b^{2}} \Delta V_{f 1-3}, \Delta_{2-3}=\delta_{1-3}+\delta_{2-3}=\frac{l^{3}}{E A b^{2}}\left(\frac{\Delta V_{f 1-3}}{\chi_{1}}+\frac{\Delta V_{f 2-3}}{\chi_{2} \beta}\right)
$$

下層の降伏せん断耐力 $V_{f l y}$ で表すと，(16)，(17)，(20)式から上下 層に作用寸るせん断力の増分 $\Delta V_{f 1-3}, \Delta V_{f 2-3}$ は次式となる。

$$
\begin{aligned}
& \Delta V_{f 1-3}=\frac{\left(\mu-\mu_{s}\right) \chi_{1}\left\{2 \beta \chi_{2}+3 \alpha(\varphi+1)\right\}}{2\left\{\beta \chi_{2}+\varphi \chi_{1}+3 \alpha(\varphi+1)\right\}}\left\{\frac{2 \varphi+3 \alpha(\varphi+1)}{2 \beta+3 \alpha(\varphi+1)}+1\right\} V_{f 1 y} \\
& \Delta V_{f 2-3}=\frac{\beta \chi_{2}\left(\mu-\mu_{s}\right)\left\{2 \varphi \chi_{1}+3 \alpha(\varphi+1)\right\}}{2\left\{\beta \chi_{2}+\varphi \chi_{1}+3 \alpha(\varphi+1)\right\}}\left\{\frac{2 \varphi+3 \alpha(\varphi+1)}{2 \beta+3 \alpha(\varphi+1)}+1\right\} V_{f 1 y}
\end{aligned}
$$

また，上下層の水平変位の増分 $\delta_{1-3}, \Delta_{2-3}$ は，(20) (22)式より次式と なる。

$$
\delta_{1-3}=\frac{\left(\mu-\mu_{s}\right)\left\{2 \beta \chi_{2}+3 \alpha(\varphi+1)\right\}}{2\left\{\beta \chi_{2}+\varphi \chi_{1}+3 \alpha(\varphi+1)\right\}}\left\{\frac{2 \varphi+3 \alpha(\varphi+1)}{2 \beta+3 \alpha(\varphi+1)}+1\right\} \frac{l^{3}}{E A b^{2}} V_{f 1 y}
$$

$$
\Delta_{2-3}=\left(\mu-\mu_{s}\right) \Delta_{2 y}=\left(\mu-\mu_{s}\right)\left\{\frac{2 \varphi+3 \alpha(\varphi+1)}{2 \beta+3 \alpha(\varphi+1)}+1\right\} \frac{l^{3}}{E A b^{2}} V_{f 1 y}
$$

また，全ての柱材に作用寸るせん断力増分 $\Delta V_{c-3}$ は，下層の降伏せん 断耐力 $V_{f 1 v}$ により次式で表される。

$$
\Delta V_{c-3}=\frac{3 \alpha(\mu-1)\left(\beta \chi_{2}-\varphi \chi_{1}\right)}{2\left\{\beta \chi_{2}+\varphi \chi_{1}+3 \alpha(\varphi+1)\right\}}\left\{\frac{2 \varphi+3 \alpha(\varphi+1)}{2 \beta+3 \alpha(\varphi+1)}+1\right\} V_{f 1 y}
$$

4)層間変形集中率の算定

任意の塑性率 $\mu$ のきの各層の変位を求めるには, 1)〜3)のどの段階 であるかを調べる必要がある。そして, 各層の変位は各段階の変形量 の総和として次のように表される。

$$
\begin{aligned}
& \delta_{1}=\sum_{i=1}^{N} \delta_{1-i} \\
& \Delta_{2}=\sum_{i=1}^{N} \Delta_{2-i}
\end{aligned}
$$

ここで, $N$ は 1)〜3)のうち, 該当する段階を示している。上式より 層間変形集中率挝次式で表される。

$$
\gamma=\frac{\operatorname{MAX}\left(\left[\Delta_{2}-\delta_{1}\right], \delta_{1}\right) / h}{\Delta_{2} / H}
$$

1)～3)の変形状態における各柱材の作用モーメントの合計は，(6), (15)，(25)式の上下層柱材の作用せん断力により次式で与えられる。

$$
M_{c}=\sum_{i=1}^{N} V_{c-i} h
$$

5)等価柱材曲げ剛性比の算定

任意の層間変形集中率 $\gamma$ となるブレース材二次剛性比 $\chi_{i}$ と柱材曲げ 剛性比 $\alpha$ の関係を， $\chi_{i}=0$ のときの $\alpha$ に等価に置き換える。このとき， $\alpha$ を等価柱材曲げ岡性比 $\alpha_{0}$ と定義する。 $\alpha_{0}$ を求めるには, 1)〜3)の 3 段 階に分類して求める必要がある。1)の場合， 梳ブレース材二次剛性 比 $\chi_{i}$ によらない。2)の場合，(5)，(13)，(14)式を(28)式に代入すること で, 任意のブレース材二次剛性比 $\chi_{i}$ に対して,$\chi_{i}=0$ の場合の等価柱材 曲げ剛性比 $\alpha_{0}$ が求められる。3)の場合も同様に, (5) , (13), (14), (23),

(24)式を(28)式に代入することで $\alpha_{0}$ が求められる。

\section{3 損傷制御型二層ブレース構造物の層間変形集中に対するブレ 一ス材二次剛性の影響}

図 2 は, 塑性率が層間変形集中率に及ぼす影響を調べるために, (28) 式及び静的解析結果を比較したものである。縦軸は層間変形集中率 $\gamma$ であり，横軸は塑性率 $\mu$ である。各線は(28)式で示されるように，上下 層の層間変形角のうち, 大きい方の值をブレース架構頂部の水平変形 角で除したものであり，二層構造物の場合 $1 \leqq \gamma \leqq 2$ の範囲となる。各 プロットは静的解析結果である。静的解析には DRAIN2DX ${ }^{15}$ を使用し ており, 図 1 の数值解析モデルで $b=900 \mathrm{~cm}, h=360 \mathrm{~cm}$ としている。せ 儿断剛性・耐力比 $\beta=5 / 6$ である。図 2(a)で上下層ブレース材二次剛性 比 $\chi_{i}$ が等しい場合, (a-1) $\alpha=0.01$ では $\chi_{i}$ が大きいほど, 塑性率 $\mu$ の増加

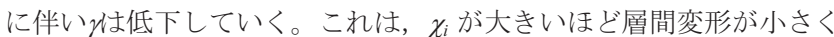
なるためである。また，折れ点は上下層降伏時の塑性率 $\mu_{s}$ であり， $\chi_{i}$ が大きいほど上層ブレース材は早期に降伏する。そして, 上下層とも に降伏すると層間変形集中率恃急激に低下寸る。これは，上層ブレ 一ス材が弾性である場合，下層のみに層間変形が集中していたが，上 層ブレ一ス材降伏後, 上層の層剛性が低下し, 上層の層間変形も急激 に増加したためである。(a-2) $\alpha=0.1$ では $\chi_{i}$ によらず怵概敉等しい。 柱材曲げ剛性が大きくなると, 早期に応力再配分が進み, $\chi_{i}$ の違いに 


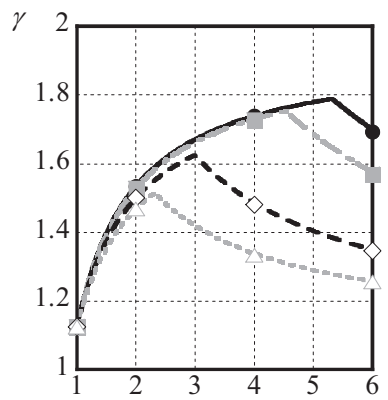

(a-1) $\alpha=0.01$

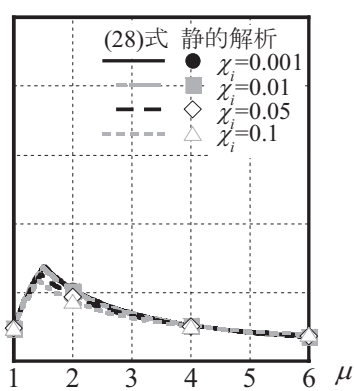

(a-2) $\alpha=0.1$

(a)上下層ブレース材二次剛性比 $\chi_{i}$ が等しい場合

図 2 層間変形集中率と塑性率 $(\beta=5 / 6)$

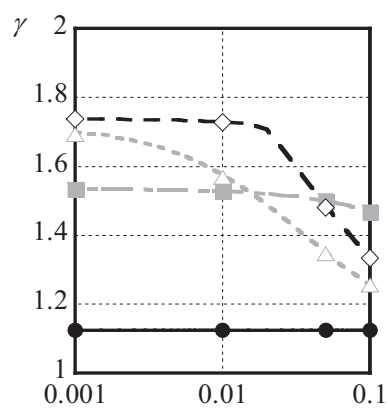

(a-1) $\alpha=0.01$

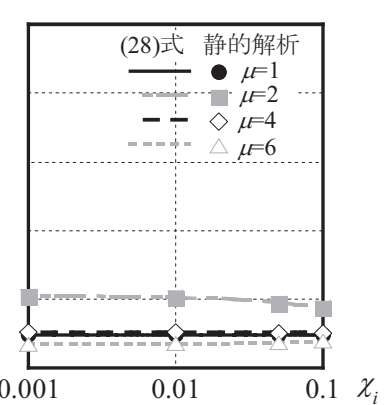

(a-2) $\alpha=0.1$

(a)上下層ブレース材二次剛性比 $\chi_{i}$ が等しい場合

図 3 層間変形集中率とブレース材二次剛性比 $(\beta=5 / 6)$

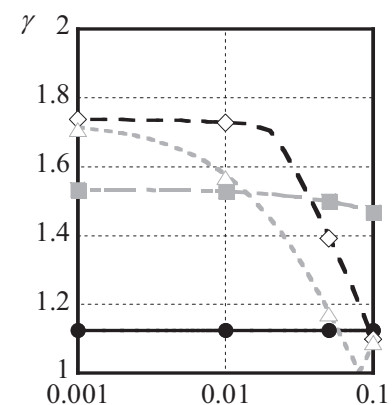

(b-1) $\alpha=0.01$

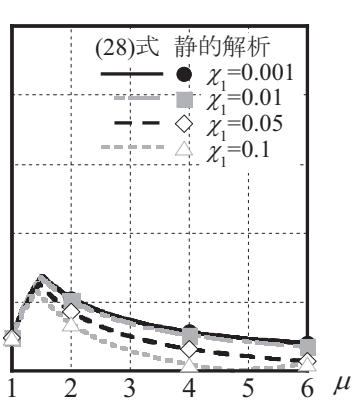

(b-2) $\alpha=0.1$

(b-1) $\alpha=0.01$

(b) 下層ブレース材二次剛性比 $\chi_{1}$ が異なる場合 $\left(\chi_{2}=0.01\right)$

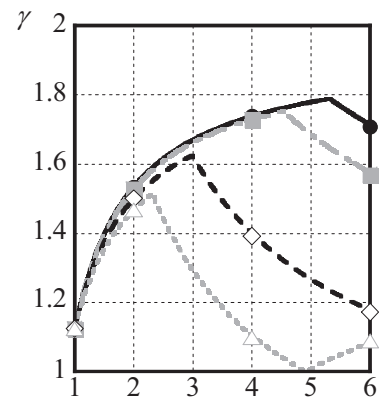

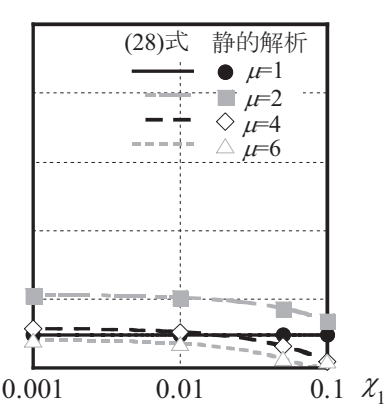

(b-2) $\alpha=0.1$

(b)下層ブレース材二次剛性比 $\chi_{1}$ が異なる場合 $\left(\chi_{2}=0.01\right)$

よる $\mu_{s}$ の差は小さくなり, そして上下層降伏後の層剛性はほぼ等し くなるためである。図 2(b)下層ブレース材二次剛性比 $\chi_{1}$ が異なる場 合 $\left(\chi_{2}=0.01\right),(\mathrm{b}-1) \alpha=0.01$ では(a-1) と同様, $\chi_{1}$ が大きいほど, $\mu$ の増加 に伴い怟下していく。これは， $\chi_{1}$ が大きいほど下層の層間変形が 小さくなるためである。また， $\chi_{1}=0.1$ の場合， $\mu$ が概ね 5 を超えると 上層に層間変形が集中するため, $\psi$ 増加していく。(b-2) $\alpha=0.1$ の場 合も (a-2) と同様， $\mu_{s}$ まではね概效等しい。そして， $\mu_{s}$ 以降は $\chi_{1}$ が大 きいほど, $\mu$ の増加に伴い壮低下寸る。 $\chi_{1}=0.1$ では, (b-1)と同様, $\mu$ が概ね 5 を超えると下層から上層に層間変形集中が変化するため, 再 びねは増加していく。

図 3 は, 上下層ブレース材二次剛性比がブレース架構の層間変形 集中率に及ぼす影響を調べるために, 塑性率をパラメータとして(28) 式及び静的解析結果を比較したものである。縦軸は層間変形集中率 $\gamma$ であり, 横軸はブレース材二次剛性比 $\chi_{i}$ である。せん断岡性・耐力比 $\beta=5 / 6$ である。図 3(a)上下層ブレース材二次剛性比 $\chi_{i}$ が等しい場合,
下層ブレース材降伏時である $\mu=1$ では(a-1)，(a-2)ともに $\chi_{i}$ によらず $\gamma$ は一定となる。(a-1) $\alpha=0.01$ では, $\mu=2$ のとき上層が弾性であるため, 神が大きくても下層ブレース材の負担層せん断力が大きくなるだけ で, ブレース架構のメカニズムに変化はない。その負担量の増加の 割合は小さいことから， $\gamma$ は $\chi_{i}$ によらずほぼ一定となる。 $\mu=4$ のき $\chi_{i}=0.02$ 以上では上下層が降伏し, 上下層ともに層間変形はほぼ一様 に増加するため, 降伏しており， $\chi_{i}$ が大きくなるほど 怟下していく。(a-2) $\alpha=0.1$ で は, 灶敉によらずほぼ一定の值となる。これは, 柱材の曲げ岡性比 $\alpha$ $\alpha$ 大きいと, ブレース材降伏後の柱材の負担せん断力はブレース材 に対して相対的に大きくなることから， $\chi_{i}$ の大きさによらず層間変形 集中を抑制するためである。また， しているため, 值は小さくなっている。図 3(b)下層ブレース材二 次剛性比 $\chi_{1}$ が異なる場合 $\left(\chi_{2}=0.01\right)$, 下層ブレース材降伏時 $\mu=1$ では $\chi_{1}$ によらず

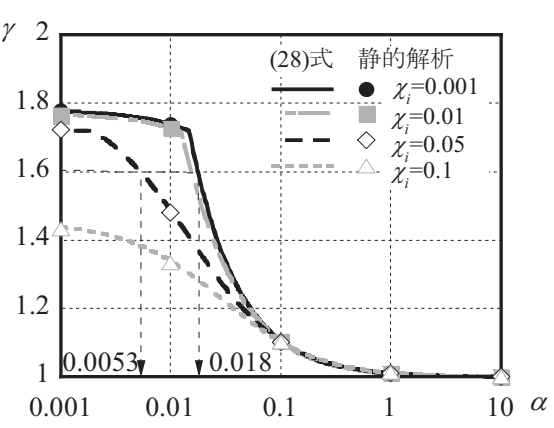

(a)上下層ブレース材二次剛性比 $\chi_{i}$ が等しい場合

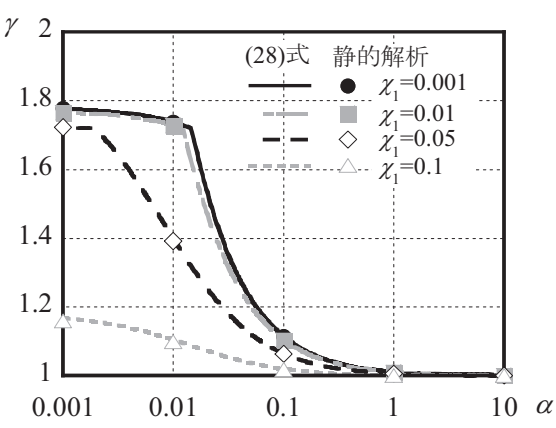

(b)下層ブレース材二次剛性比 $\chi_{1}$ が異なる場合 $\left(\chi_{2}=0.01\right)$

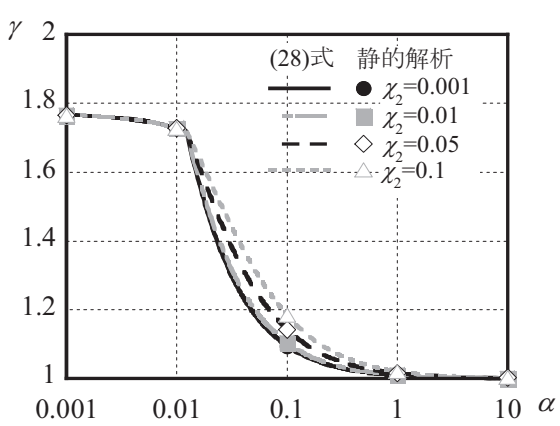

(c)上層ブレース材二次剛性比 $\chi_{2}$ が異なる場合 $\left(\chi_{1}=0.01\right)$

図 4 層間変形集中率と柱材曲げ剛性比 $(\beta=5 / 6, \mu=4)$ 


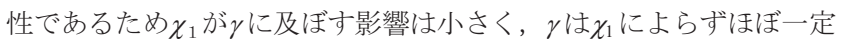
となる。 $\mu=4$ のとき $\chi_{i}=0.02$ 以上では上下層ともに降伏しているため 上層の層間変形が増加し,, は急激に低下寸る。 $\mu=6$ のとき $\chi_{1}=0.001$ では上下層降伏後間もないため, 下層に層間変形が集中しているも のの， $\chi_{1}$ が大きいほじ塑性化した上層の層間変形は増加するため, $\gamma$ は小さくなる。そして, $\chi_{1}$ が約 0.08 で $\gamma=1$ となり, $\chi_{1}$ が約 0.08 を超え ると，上層に層間変形が集中寸るため，挝再び大きくなる。

図 4 は, 柱材曲げ岡性比がブレース架構の層間変形集中率に及ぼ す影響を調べるため, 上下層ブレース材二次剛性比をパラメータと して(28)式と静的解析結果を比較している。縦軸は層間変形集中率 $\gamma$ であり，横軸は柱材曲げ岡性比 $\alpha$ である。せん断剛性・耐力比 $\beta=5 / 6$, 塑性率 $\mu=4$ の場合を示している。図 4(a)上下層ブレース材二次剛性比 $\chi_{i}$ が等しい場合, $\alpha=0.001$ では $\chi_{i}$ が大きいほど る。 $\alpha$ が大きくなると, 全ての $\chi_{i}$ で早期に上下層のブレース材がほぼ 同時に降伏するため, 忙に収束していく。柱材の作用せん断力は上 下層ブレース材による層せん断力の差であり, 柱材は心棒のように 上下層の層間変形を均一化する効果を有することが分かる。図 4(b) 下層ブレース材二次剛性比 $\chi_{1}$ が異なる場合 $\left(\chi_{2}=0.01\right), \chi_{1}=0.1$ において $\alpha=0.001$ では，上下層ともに降伏しており， $\gamma$ 低下している。図4(a) と同様， $\alpha$ 大゙きくなると上下層ブレース材がほぼ同時に降伏するた め, 杜1に収束していく。(c)上層ブレース材二次剛性比 $\chi_{2}$ が異なる 場合 $\left(\chi_{1}=0.01\right), \alpha=0.001 \sim 0.01$ 程度では上層が弾性であるため, $\chi_{2}$ によ らず挝等しい。 $\alpha$ が約 0.01 を超えると上下層ともに降伏しており, $\alpha=0.01 \sim 1$ 程度では $\chi_{2}$ が $\chi_{1}$ に近い值ほど上層の層間変形が下層とほぼ 等しくなるため， 惊小さくなる。そして， $\alpha$ が大きくなると上下層 ブレース材はほぼ同時に降伏するため，恃 1 に収束していく。

図 5 にブレース材二次剛性比と等価柱材曲げ剛性比の関係を $\gamma=1.1 \sim 1.6$ について(28)式を用いて表している。縦軸はブレース材二次 剛性比 $\chi_{i}$ であり, 横軸は等価柱材曲げ剛性比 $\alpha_{0}$ である。ここで, $\alpha_{0}$ は2．2節5)で定義したものである。せん断剛性・耐力比 $\beta=1,5 / 6$ で塑性率 $\mu=4$ の場合について, $\beta=1$ を黒線， $\beta=5 / 6$ を灰色線としてい る。等しいれおける $\alpha_{0}$ の值は完全弾塑性の場合よりブレース材が二 次剛性を有する場合の方が小さくなる。例えば, $\beta=5 / 6, \gamma=1.6$ となる ときの $\chi_{i}$ と $\alpha_{0}$ の組み合わせは $\chi_{i}=0$ では $\alpha_{0}=0.018$ 程度, $\chi_{i}=0.05$ では $\alpha_{0}=0.0053$ 程度となる。 $\chi_{i}=0.05$ のときの $\alpha_{0}$ は $\chi_{i}=0$ のときの約 $1 / 3$ に相当 する。また, せん断剛性・耐力比 $\beta$ が大きいほど, 層間変形は下層に

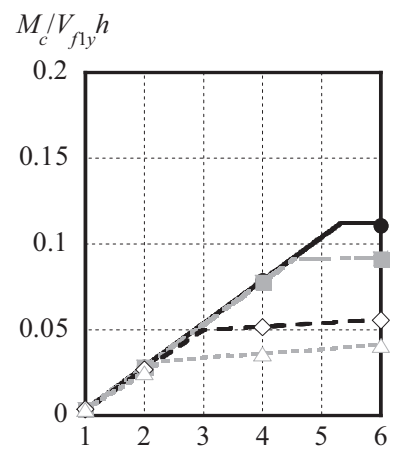

(a-1) $\alpha=0.01$

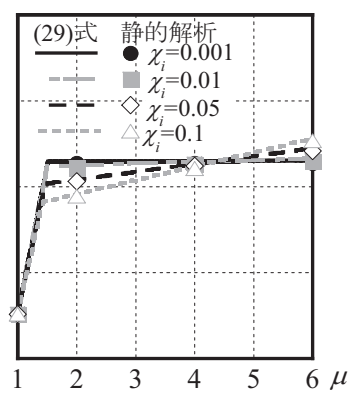

(a-2) $\alpha=0.1$ (a)上下層ブレース材二次剛性比 $\chi_{i}$ が等しい場合

図 6 柱材作用モーメントと塑性率 $(\beta=5 / 6)$

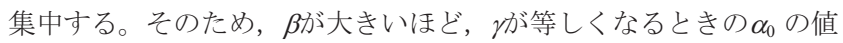
は大きくなる。

\section{4 損傷制御型二層ブレース構造物の柱材作用モーメントに対 するブレース材二次剛性の影響}

図 6 に塑性率が柱材に作用するモーメントに及ぼす影響を調べる ために, 上下層ブレース材二次剛性比をパラメータとして(29)式と静 的解析結果を比較している。縌軸は柱材作用モーメント $M_{c}$ を下層の 降伏せん断耐力に階高を乗じた $V_{f 1 y} h$ で除したものであり, 横軸は塑 性率 $\mu$ あ゙る。せん断剛性・耐力比 $\beta=5 / 6$ の場合を示している。図 6(a) 上下層ブレース材二次剛性比 $\chi_{i}$ が等しい場合, (a-1) $\alpha=0.01$, (a-2) $\alpha=0.1$ ともに $\chi_{i}$ によらず, $\mu$ 増加の伴い, $M_{d} / V_{f y} h$ は等しい傾きで上 昇していく。 $M_{c}$ は上下層の負担せん断力の差に階高を乗じることで 求められるが, 初期勾配時では, 上層は弾性であるため, 上下層の 負担せん断力の差に対して $\chi_{i}$ の影響は小さい。また, 折れ点は上下層 降伏時の塑性率 $\mu_{s}$ であり, $\chi_{i}$ が大きいほど上層は早期に降伏し, その ときの $M_{d} V_{f l y} h$ は小さくなっている。そして, 折れ点以降, 寸なわち 上下層降伏後の $M_{d} / V_{f l y} h$ の第二勾配は $\chi_{i}$ が大きいほど高くなっている。 (a-2) $\alpha=0.1$ では $\chi_{i}$ が大きいほど上下層降伏時の $M_{c} / V_{f y} h$ の值は低いも のの, 第二勾配が高いため, $\mu=4$ で $M_{c} / V_{f y} h$ はほぼ等しくなり, $\mu$ が ほぼ 4 を超えると $\chi_{i}$ が大きいほど $M_{d} / V_{f 1 y} h$ は大きくなる。図 6(b) 下層 ブレース材二次剛性比 $\chi_{1}$ が異なる場合 $\left(\chi_{2}=0.01\right),(\mathrm{b}-1) \alpha=0.01$ では(a-1) と同様， $\chi_{1}$ が大きいほど上層は早期に降伏し，そのときの $M_{d} / V_{f l y} h$ は 小さくなる。上下層降伏後, $M_{c} / V_{f 1} h$ の第二勾配は， $\chi_{1} \leqq \chi_{2}$ であれば 正勾配となり， $\chi_{1}>\chi_{2}$ であれば負勾配となる。そのため， $\chi_{1}$ が大きい

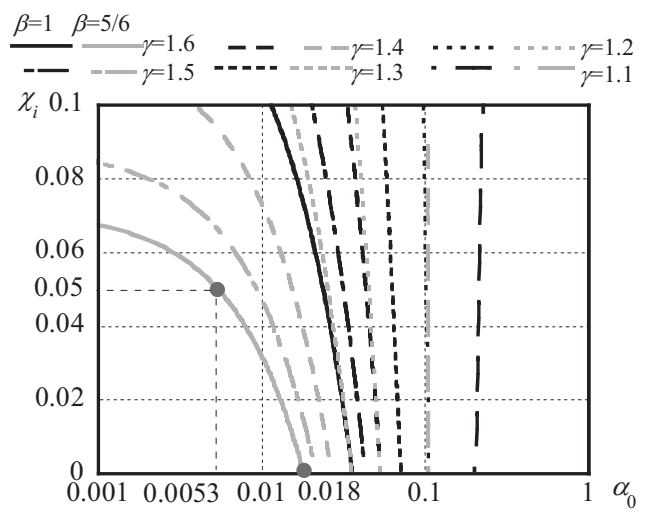

図 5 ブレース材二次剛性比と等価柱材曲げ岡性比 $(\beta=1,5 / 6, \mu=4)$

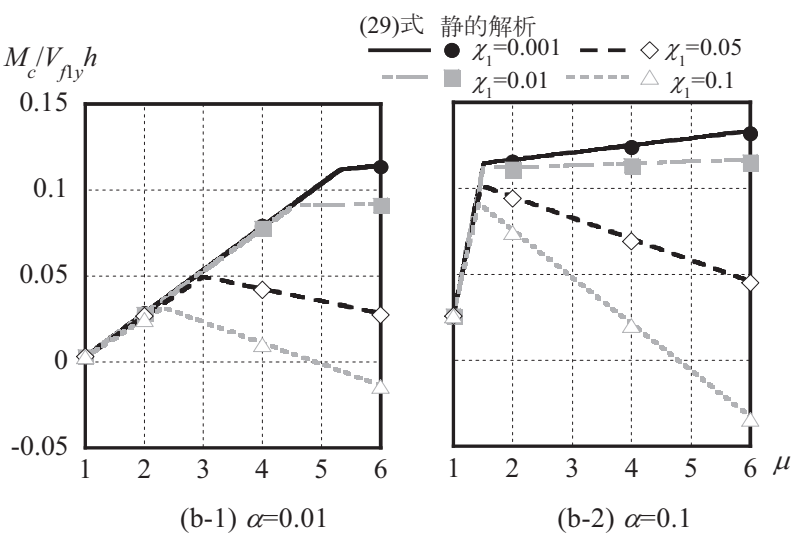

(b)下層ブレース材二次剛性比 $\chi_{1}$ が異なる場合 $\left(\chi_{2}=0.01\right)$ 


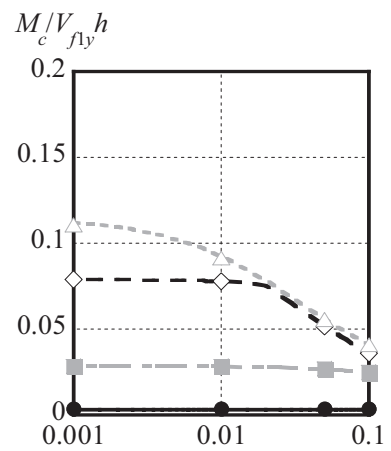

(a-1) $\alpha=0.01$

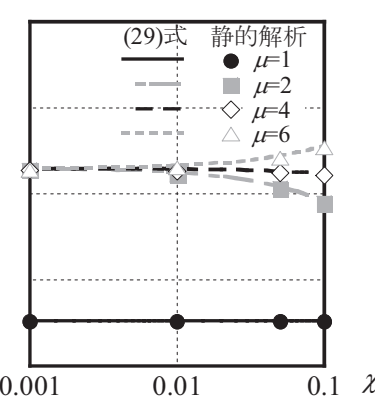

(a-2) $\alpha=0.1$

(a)上下層ブレース材二次剛性比 $\chi_{i}$ が等しい場合 図 7 柱材作用モーメントとブレース材二次剛性比 $(\beta=5 / 6)$

ほど, $\mu$ の増加の伴い $M_{d} / V_{f y} h$ は小さくなる。(b-2) $\alpha=0.1$ では, 折れ 点となるときの $\mu_{s}$ の值は $\chi_{i}$ によらずほぼ等しい。 $\chi_{1} \leqq \chi_{2}$ では $M_{c} / V_{f 1} h$ は $\mu$ に対して正勾配となり, $\chi_{1}>\chi_{2}$ では $M_{c} / V_{f 1 y} h$ は負勾配となるため, $\mu の$ 増加に伴い $M_{d} / V_{f 1 y} h$ 差は大きくなっていく。

図 7 は，ブレース材二次剛性比が柱材に作用するモーメントに及 ぼす影響を調べるために，(29)式と静的解析結果を比較している。横 軸はブレース材二次剛性比 $\chi_{i}$ である。せん断剛性・耐力比 $\beta=5 / 6$ の場 合を示している。図 7(a)上下層ブレース材二次剛性比 $\chi_{i}$ が等しい場合, (a-1) $\alpha=0.01$ では上層が弾性のとき, $M_{d} V_{f 1} h$ はほぼ一定である。上下 層降伏後， $\chi_{i}$ が大きいほど $M_{c} / V_{f y} h$ は小さくなる。これは，図 6(a-1) でも上層が弾性であれば $\chi_{i}$ によらず, $M_{c} / V_{f 1} h$ はほぼ等しくなり,$\chi_{i}$ が大きいほど上層は早期に降伏し， $M_{d} / V_{f y} h$ は小さくなることからも 分かる。(a-2) $\alpha=0.1$ では, $\mu=1,2$ のとき(a-1) $\alpha=0.01$ と同様の傾向を 示すが, $\mu=4$ では $\chi_{i}$ の值によらず $M_{c} V_{f 1} h$ はほぼ一定のままであり, $\mu=6$ のとき $\chi_{i}$ が大きいほど $M_{c} / V_{f 1 y} h$ は大きくなっている。これは, 図 $6(\mathrm{a}-2)$ で $\mu 4$ のとき $M_{d} / V_{f l y} h$ の值はほぼ等しくなり， $\mu=6$ のとき第二 勾配が大きいほど $M_{d} V_{f l y} h$ が大きくなることからも分かる。図 7(b) 下層ブレース材二次剛性比 $\chi_{1}$ が異なる場合 $\left(\chi_{2}=0.01\right)$, (b-1) $\alpha=0.01$, (b-2) $\alpha=0.1$ ともに, 下層のみ降伏しているときの $M_{d} / V_{f 1} h$ は $\chi_{1}$ によら ずほぼ一定である。上下層降伏後, $\chi_{1}$ が大きいほど $M_{d} / V_{f 1} h$ は小さく なる。これは, 図 6(b-1), (b-2)で上層が弾性のとき, $\chi_{1}$ にらず $M_{d} / V_{f 1} h$ はほぼ等しくなり， $\chi_{1}$ が大きいほど上層は早期に降伏し， $M_{d} / V_{f y} h$ は

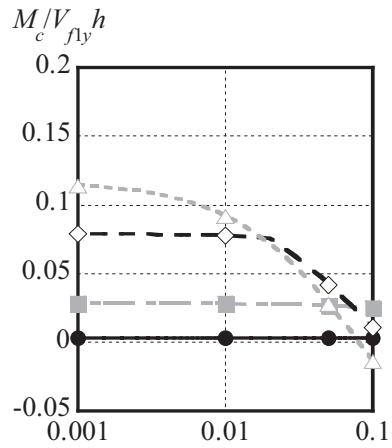

(b-1) $\alpha=0.01$

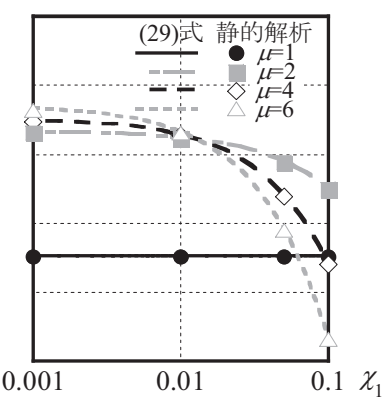

(b-2) $\alpha=0.1$ (b)下層ブレース材二次剛性比 $\chi_{1}$ が異なる場合 $\left(\chi_{2}=0.01\right)$
小さくなることからも分かる。また, (b-2) $\alpha=0.1$ では, (b-1) $\alpha=0.01$ より $\chi_{1}$ が大きいほど $M_{c} / V_{f 1 y} h$ は急激に低下していく。これは, 図 6(b-2) では図 6(b-1)に比べて $\chi_{i}$ による上下層降伏後の $M_{c} / V_{f 1} h$ の傾きが大き く異なるためである。

図 8 は, 柱材曲げ岡性比が柱材に作用するモーメントに及ぼす影響 を調べるために，(29)式と静的解析結果を比較したものである。横軸 は柱材曲げ岡性比 $\alpha$ である。せん断剛性・耐力比 $\beta=5 / 6$ で塑性率 $\mu=4$ の場合を示している。図 8(a)上下層ブレース材二次剛性比 $\chi_{i}$ が等しい とき, $\alpha=0.0001 \sim 0.1$ 程度では $\chi_{i}$ が大きいほど, 上下層ブレース材降伏 時の塑性率 $\mu_{\mathrm{s}}$ は小さいため, $M_{d} / V_{f 1 y} h$ は小さくなる。一方, $\alpha>0.1$ では $\chi_{i}$ の違いによる $\mu_{\mathrm{s}}$ の差は小さいため, $\chi_{i}$ が大きいほど, $M_{c} / V_{f 1 y} h$ は大 きくなる。ブレース材が完全弾塑性 $\left(\chi_{i}=0\right)^{3)}$ のとき, $M_{d} / V_{f 1 y} h=0.1$ が上 限となるが, ブレース材二次剛性を有すると, $\alpha$ 増加により $M_{c} / V_{f y} h$ も増加していく。図 8 (b) 下層ブレース材二次剛性比 $\chi_{1}$ が異なる場 合 $\left(\chi_{2}=0.01\right), \quad \chi_{1}$ が大きいほど $M_{d} / V_{f l y} h$ は小さくなる。 $M_{d} / V_{f y} h$ の上下 層降伏後の第二勾配は $\chi_{1}=0.001,0.01$ では正勾配， $\chi_{1}=0.05,0.1$ では 負勾配となり，そして $\chi_{1}$ が大きいほど $M_{d} / V_{f l y} h$ の第二勾配は急勾配と なることから， $M_{d} / V_{f 1} h$ は小さくなる。図 8(c)上層ブレース材二次剛 性比 $\chi_{2}$ が異なる場合 $\left(\chi_{1}=0.01\right), \alpha=0.001 \sim 0.01$ 程度では上層は弾性であ るため, $\chi_{2}$ によらず $M_{d} / V_{f 1 y} h$ は等しくなる。上下層ともに降伏する $\alpha$ $\geqq 0.01$ では, $\chi_{2}$ が大きいほど $M_{d} / V_{f 1} h$ は大きくなり, $\chi_{2}=0.1$ では $\alpha=10$ で $M_{c} / V_{f 1} h=0.25$ まで達する。
(29)式 静的解析

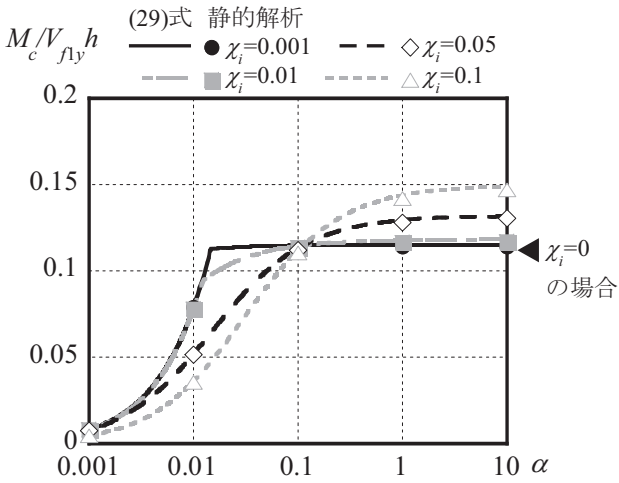

(a)上下層ブレース材二次剛性比 $\chi_{i}$ が等しい場合

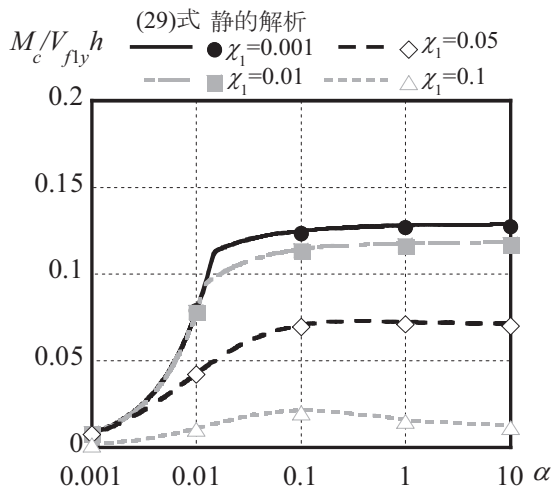

(b)下層ブレース材二次剛性比 $\chi_{1}$ が異なる場合 $\left(\chi_{2}=0.01\right)$
(29)式 静的解析

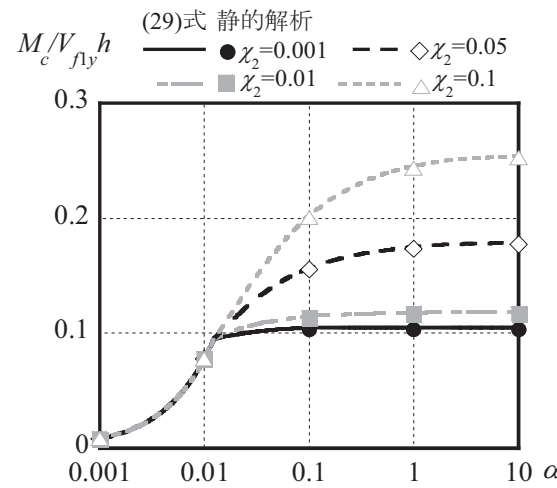

(c)上層ブレース材二次剛性比 $\chi_{2}$ が異なる場合 $\left(\chi_{1}=0.01\right)$

図 8 柱材作用モーメントと柱材曲代剛性比 $(\beta=5 / 6, \mu=4)$ 
3. ブレース材二次剛性を有する損傷制御型二層ブレース構造物の 地震応答性状

本章では，前章における静的地震外力の釣合いより得られた層間 変形集中及び柱材作用モーメントを元に，ブレース架構が損傷を生 じるレベルの強震を受ける場合の動的効果を検討する。

\section{1 二層ブレース構造物の動的応答解析概要}

2 章で誘導された層間変形集中率式及び柱材作用モーメントの算定 式 [(28)式, (29)式 $]$ と複数の観測地震波による地震応答解析結果を 比較し, これらの算定式の適用の可能性を検証する。解析に用いるブ レース架構モデルは図 1 と同様の形状とし, ブレース架構の一スパン $b=900 \mathrm{~cm}$, 層高 $h=360 \mathrm{~cm}$ とする。また, ブレース材の断面積 $A_{b}=30 \mathrm{~cm}^{2}$ とし, 降伏応力 $\sigma_{y}=235 \mathrm{~N} / \mathrm{mm}^{2}$ とする。柱材の断面性能は柱材曲げ岡性 比 によって異なり，(1)式より求められる。各層の質量は文献 4) と同 様, 一スパンあたり 120ton とする。ブレース架構の保有水平耐力時 のベースシア係数は 0.56 となる。構造物の粘性減衰は Rayleigh 型で, 1 次と 2 次の減衰定数は $2 \%$ である。数值解析は Newmark- $\beta$ 法 $(\beta=0.25)$ で, 時間成分刻みは1/1000秒である。地震波はEL Centro 1940 NS/ EW, Hachinohe 1968 NS/ EW, Kobe 1995 NS/ EW, Taft 1952 NS/ EW, Tohoku 1978 NS/ EW の 10 種類とし, ブレース架構に強震が作用し, 塑性変 形が生じる場合ブレース架構の塑性率と層間変形集中との関係を明 らかにする。

3. 2 二層ブレース構造物の動的応答性状に対する弾性柱材の効果 解析対象はせん断剛性・耐力比 $\beta$ が $1,5 / 6,2 / 3$ の場合のブレース 架構であり，柱材曲げ岡性比 $\alpha$ は $0.001 ， 0.01 ， 0.1 ， 1.0,10$ である。

図 9 にベースシア係数 $C_{b}=0.56, \beta=5 / 6$ のブレース架構において, 最 大層間塑性率が生じる層での応答変位時刻歴を示す。地震波は $\mathrm{EL}$ Centro 1940 NS である。(a)は $\alpha=0.01 ， \chi_{i}=0.001 ，(b)$ は $\alpha=1 ， \chi_{i}=0.001$, (c)は $\alpha=0.01, \chi_{i}=0.1$ について示したものである。縦軸は下層の層間塑 性率 $\mu_{1}$ である。(a) $\alpha=0.01 ， \chi_{i}=0.001$ では, $t=4.5 \sim 12.0$ (s)の間で $\mu_{1}=4.0$ 程度に達し, その後片振りし, $\mu_{1}=1.8$ 程度を中心として振動している。 (b) $\alpha=1, \chi_{i}=0.001$ では, (a) と同様, $\chi_{i}=0.001$ であるが柱材曲げ岡性比 $\alpha$ が大きいため, $\mu_{1}$ は最大 2.0 程度と小さいものの, 残留変形を生じて いる。(c) $\alpha=0.01, \chi=0.1$ では, (a) と比較するとブレース材二次剛性比 $\chi_{i}$ が大きいため, $\mu_{1}$ は 2.0 程度に低減されている。また, 最大変形後 の残留変形もほとんど生じていない。残留変形の抑制には, 柱材曲げ 剛性よりもブレース材の二次剛性が寄与していることが分かる。

図 10 に図 9 と同じブレース架構において, 最大モーメントを生じ
る位置での応答モーメント時刻歴を示す。縦軸は柱材の最大作用モー メント $M_{c}$ を, 下層の降伏せん断耐力 $V_{f l y}$ に層高 $h$ を乗じた值で除し たものである。(a) $\alpha=0.01, \chi_{i}=0.001$ では, $t=4.5 \sim 12.0(\mathrm{~s})$ 間で $M_{d} / V_{f 1} h$ は最大となり, 約 0.05 である。(b) $\alpha=1, \chi_{i}=0.001$ では, $\alpha$ 大゙大きた め, 最大 $M_{d} / V_{f l y} h=0.27$ 程度と, (a)の 7 倍程度になっている。(c) $\alpha=0.01$, $\chi_{i}=0.1$ の場合ブレース材二次剛性比 $\chi_{i}$ が大きいため, (a)の場合よりも $M_{c} / V_{f l y} h$ は小さい。

図 11 に地震波について最大層間塑性率が生じるときの上下層の応 答せん断力比 $V_{s 2} / V_{s 1}$ を示す。各プロットは EL Centro $1940 \mathrm{NS} / \mathrm{EW}$, Hachinohe 1968 NS/ EW, Kobe 1995 NS/ EW, Taft 1952 NS/ EW, Tohoku 1978 NS/ EW である。図中の太線は柱材曲げ岡性比ごとに $V_{s 2} / V_{s 1}$ の平 均值を示している。各応答解析結果はばらついているが, その平均 值は $0.619 \sim 0.652$ となっており，2 章の静的解析で $\mathrm{A}_{\mathrm{i}}$ 分布により 仮定した上下層のせん断力比 $\varphi=0.644$ と概袮等しくなっている。

\section{3 二層ブレース構造物の動的層間変形及び動的作用モーメント 評価}

図 12 に地震外力を受ける二層ブレース構造物の層間変形集中率及 び柱材作用モーメントを，静的釣り合いにより誘導した(28), (29)式 と比較している。図 12(a)は動的層間変形集中率 $\gamma_{d}$ と(28)式より求めら れる層間変形集中率 $\gamma$ であり, 縦軸は $\gamma_{d}$, 横軸は $\gamma$ である。各プロット をブレース材二次剛性比ごとに示している。網掛けは \pm 0.2 の範囲を示 している。㠷び $\gamma_{d}$ は 1.0 から 2.0 まで幅広く分布しているが， $\gamma_{d}$ と $\gamma$ は $\chi_{i}$ の大きさによらず概衫対応しており，(28)式により動的層間変形 集中率を評価できる。図 12(b)は柱材の動的最大作用モーメント $M_{c d}$ と動的最大モーメント時の $\mu$ に対応した(29)式の柱材の静的作用モー メント $M_{c}$ であり, 縦軸, 横軸をそれぞれ下層の降伏せん断耐力に階 高を乗じた $V_{f l y} h$ で除したものとしている。 $\beta=2 / 3$ では $M_{d} / V_{f l y} h=0.014$ 前後, $\beta=5 / 6$ では $M_{d} / V_{f l y} h=0.11$ 前後, $\beta=1$ では $M_{d} / V_{f l y} h=0.22$ 前後にば らつきが見られる。これは, 静的解析結果では $\chi_{i}$ が小さいとき, 上記 の值で $M_{d} / V_{f l y} h$ がほぼ上限となり， $\alpha$ 值によらず，ほぼ一定となる ものの, 動的解析結果では慣性力の影響により上記の 3 箇所では特に 各層の最大作用せん断力が増幅・減少し, ばらつきが大きくなったも のと思われる。しかし, この 3 箇所以外では層間変形集中率と同様, $M_{c d}$ と $M_{c}$ は概ね一致しており, 動的作用モーメントも(31)式により評 価できる。ブレース架構の構造特性及び地震外力レベルを設定すれば, $S_{a}-S_{d}$ スペクトルからブレース架構に要求される変形量 (塑性率) を推 定でき ${ }^{16)}$, ブレース材が二次剛性を有する二層ブレース架構の動的層

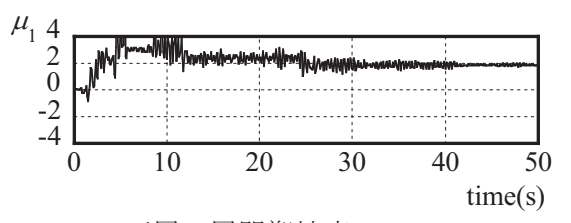

(a) 下層の層間塑性率 $\left(\alpha=0.01, \quad \chi_{i}=0.001\right)$

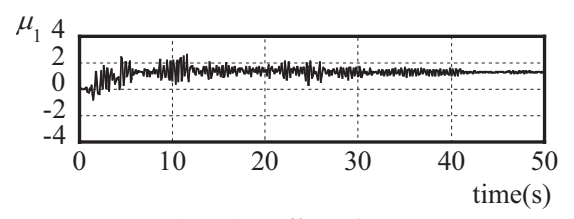

(b) 下層の層間塑性率 $\left(\alpha=1, \quad \chi_{i}=0.001\right)$

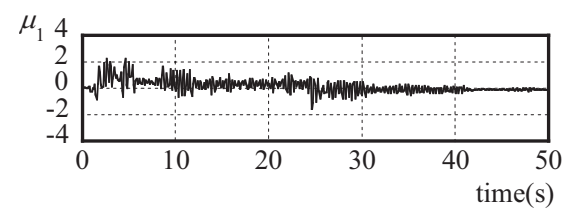

(c) 下層の層間塑性率 $\left(\alpha=0.01, \chi_{i}=0.1\right)$

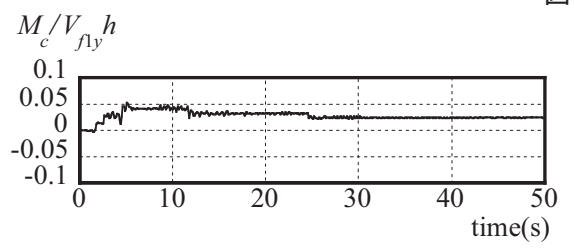

(a) $\alpha=0.01, \quad \chi_{i}=0.001$

9 最大層間塑性率が生じる層での応答変位時刻歴

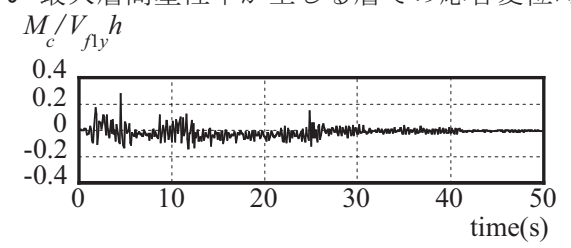

(b) $\alpha=1, \quad \chi_{i}=0.001$

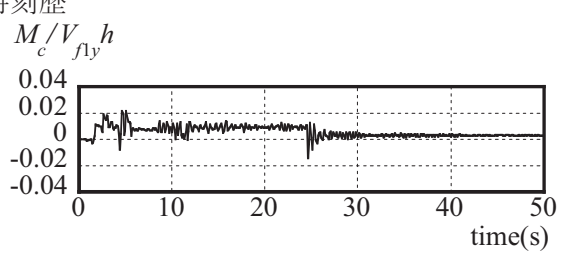

(c) $\alpha=0.01, \quad \chi_{i}=0.1$

図 10 最大モーメント位置における応答モーメント時刻歴 
間変形集中率及び動的作用モーメントはそれぞれ(28)式，(29)式より 求められる。

\section{4. 結}

本論文では，二相系構造として損傷制御型二層ブレース構造物を対 象に, 構造物に損傷を及ぼすレベルの強震が作用したとき，主抵抗要 素にブレース材, 二次抵抗要素に弾性柱材を適用したブレース架構に ついて, ブレース材の二次剛性の大きさが層間変形集中率及び柱材作 用モーメントに与える影響について検討した。以下に得られた結論を 示す。

1)静的釣合いから誘導した二層ブレース構造物の層間変形集中率は, ブレース架構の塑性率，柱材曲げ剛性比とブレース材二次剛性比の 関係より得られた(28)式で評価できる。

2)静的釣合いから誘導した二層ブレース構造物の柱材に作用する最 大モーメントは，ブレース架構の塑性率，柱材曲げ剛性比とブレー ス材二次剛性比の関係より得られた(29)式で評価できる。

3)ブレース材二次剛性は層間変形集中率を緩和する効果があるもの の，柱材作用モーメントを増加させる。また，地震後のブレース架 構の残留変形を低減させる効果もある。

4)動的効果を考慮した層間変形集中率及び動的作用モーメントは静 的釣り合いより誘導された(28)，(29)式で評価できる。すなわち，ブ レース架構に要求される塑性率を定めることで, 設計上想定される 地震動を受けるブレース架構の層間変形集中率を予測することが可 能となり，層間変形集中を抑制するための柱材断面を決定すること ができる。

\section{謝辞}

本研究は「科学研究費補助金基盤研究(C)(課題番号 19560574)」 による成果である。梁く感謝の意を表す。

\section{参考文献}

1) 川島和彦, A.Macrae, G., 星隈順一, 長屋和宏 : 残留変位応答スペク トルの提案とその適用，土木学会論文集，No.501/I-2,pp183-192,1995

2) 中島正愛, 三谷貴志, 辻文三 : 第二剛性比の高いバイリニア系のエネ ルギー入力・消費特性，構造工学論文集，vol. 42B，pp.59〜68, 1996.3

3) 日比野陽, 市之瀬敏勝: 強震を受ける 2 層鋼構造建物で塑性変形が卓 越する層を予測する方法，日本建築学会構造系論文集，第 606 号，pp105 $\sim$ pp.111, 2006.8

4) 木村祥裕，グレゴリーマクレイ：二層ブレース架構における柱材の力学性能 の違いが架構の層間変形集中に与える影響, 日本建築学会構造系論文集, 第 560 号, pp189 pp.195, 2002.10

5) Gregory A. MacRae, Yoshihiro Kimura, Charles Roeder : Effect of Column Stiffness on Braced Frame Seismic Behavior, Jour. of Structural Engineering, ASCE, Vol.130, No.3, pp.381-391, 2004.3

6) 木村祥裕, グレゴリーマクレイ : 柱脚固定された二層ブレース架構の層間変 形集中率に及ぼす柱材の曲げ岡性及び曲げ耐力の影響, 日本建築学会構造系 論文集，第 593 号，pp153〜pp.160，2005.7

7) 木村祥裕 : 損傷制御型二層ブレース構造物の層間変形集中率に対寸る弾性柱 材の抑制効果，日本建築学会構造系論文集，第 612 号, pp187〜 pp.195, 2007.2

8) 木村祥裕, 岩間聡史 : 強震を受ける損傷制御型二層ブレース構造物の 層間変形集中に対寸る柱脚回転剛性の影響, 日本建築学会構造系論 文集, 第 73 巻 628 号, pp.973-982, 2008.6

9) 秋山宏 : 建築物の耐震極限設計, 14.4 損傷分散型骨組, 東京大学出版会, 1987.9

10) 日本鋼構造協会: 履歷型ダンパー付骨組の地震応答性状と而震設計法, 1998.9

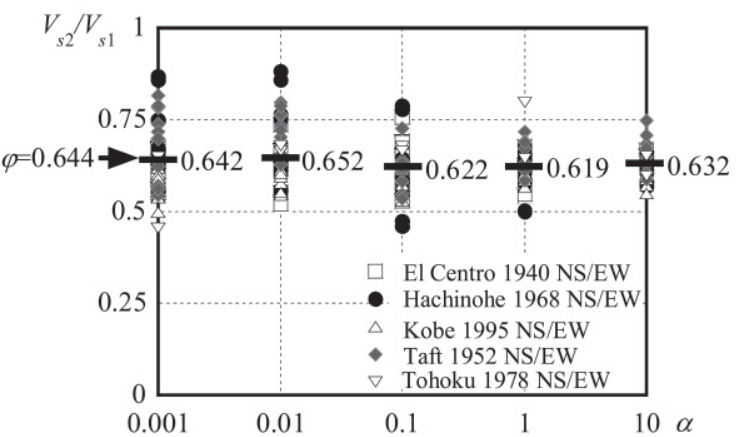

図 11 最大層間塑性率を生じるときの上下層の応答せん断力比

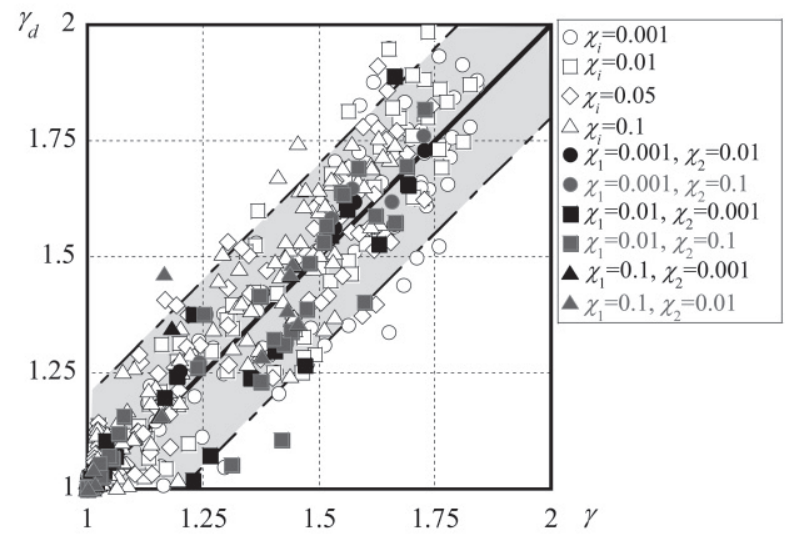

(a) 動的層間変形集中率一層間変形集中率

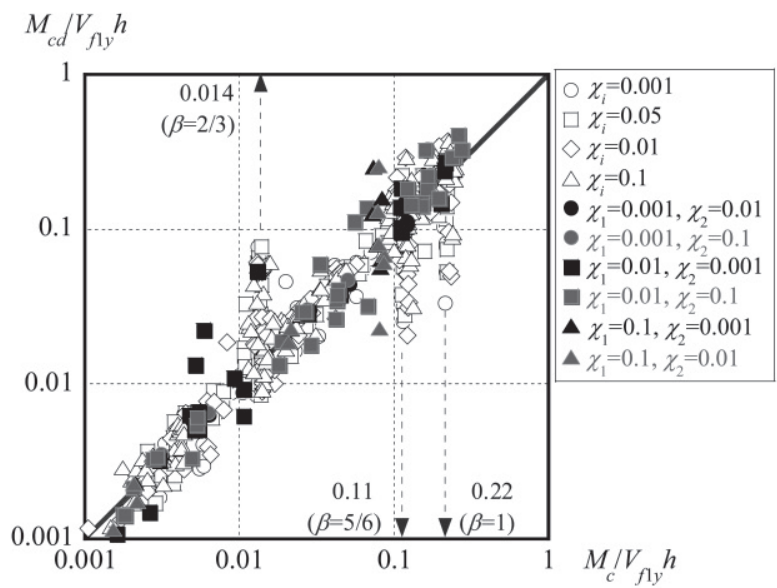

(b) 動的作用モーメントー作用モーメント

図 12 地震外力を受ける架構の動的応答評価

11) Tremblay, R : Achieving a Stable Inelastic Seismic Stability of Concentrically Braced Steel Frames, Engineering Jour. AISC, Vol.40, No.2，pp.111 129， 2003

12）多賀謙蔵, 加登美喜子, 徳田幸弘, 鶴田潤, 和田章 : ダンパー効率を高めたパ ッシブ制震構造における構造計画上の留意点と実用性, パッシブ制振構造シン ポジウム 2004, pp.105〜112, 2004.11

13) International Code Council, Inc. (ICCI) : International Building Code, 2003

14) American Institute of Steel Construction, Inc.: Seismic Provisions for Structural Steel Buildings, 2006

15) Prakash V., Powell G. H. and Campbell S. : Drain-2DX Base Program Desciption and User Guide Version 1.10, 1993

16) 国土交通省住宅局建築指導課，日本建築主事会議，日本建築センター：2001 年度版建築物の構造関係技術基淮解説書, 2001

17) 日本建築学会 : 建築而震設計における保有耐力と変形性能（1990），1990.10 